\title{
Characteristics of Salt Lake Deposition and Significance for Oil-gas
}

\section{Exploration of Xingouzui Formation, Xingou oilfield, Jianghan Basin}

\author{
Jiangyan Liu ${ }^{1, a}$, Rui Zhü, ${ }^{2, b}$ Lixin Chen ${ }^{3, c}$ \\ ${ }^{1}$ Key Laboratory of Exploration Technologies of Oil and Gas Resources of Ministry of Education, \\ School of Geosciences, Yangtze University, Wuhan 430100, Hubei, China \\ ${ }^{2}$ Key Laboratory of Exploration Technologies of Oil and Gas Resources of Ministry of Education, \\ School of Geosciences, Yangtze University, Wuhan430100, Hubei, China \\ ${ }^{3}$ Oil Production Plant in Jianghan Oilfield, SINOPEC, Qianjiang 433124,Hubei, China \\ a jiangyan19880312@163.com, b zhurui @yangtzeu.edu.cn, c464339717@qq.com
}

Key words: salt lake deposition, paleoclimate, oil-gas exploration, Xingouzui Fm, Jianghan Basin Abstract: Jianghan Basin is a typical Mesozoic-Cenozoic salt lake basin of East China, oil and gas reservoir with industrial utilization value was found in the Xingouzui Fm, Xingou Oilfield of this basin, the formation of which is closely related to the dolomite stratigraphy deposited in the salt lake. In order to explore the relationship between salt lake deposition with oil-gas reservoir and to get better understanding of the character of Jianghan Basin Salt Lake deposit to provide theoretical foundation for the exploration and development of the oil and gas resources. This paper, based on the elaboration study of the layer section core, combined with detection logging information and analysis test data, describes the salt lake deposit character according to the salt mineral species and profile thickness, makes an analysis of its formation mechanism, and discusses the salt lake deposit's indicating significance toward paleoclimate. The result suggests that the salt lake deposit of the research area demonstrate obvious feature of rhythmicity. Which shows in the alternating appearance of rhythmite composed by mudstone, dolomite, gypsum and rock salt. This kind of rhythmicity is a direct response of constantly changing of lake level rising-falling. The wide development of eury-thermal saline minerals such as calcite and dolomite, indicates that the palaeoclimate was arid to semi-arid in Jianghan Basin during the deposition of Xingouzui Formation in Paleogene. A complete salt rhythm can form a source-reservoir-seal assemblage, which has an important meaning for hydrocarbon generation, accumulation and preservation.

\section{Introduction}

Salt Lake is a kind of salinized lake formed under the control of various factors: climate condition (annual evaporation> supplementary amount),geological structure condition 、 matter source condition ${ }^{[1]}$. Salt Lake in different zones possess different economic value due to the difference of develop scale, mineral species. According to the landform, geological structure condition, materials composition characteristics which formed the salt lake, and roughly divided by almost east-west running Himalayas, the Kunlun Mountain--Altun Mountains-Qilian Mountain-Liupan Mountain, north-east running Helan Mountain and Tai-hang Mountain--Great Khingan Range, Zheng Mianping divided Chinese Salt Lake into four areas ${ }^{[1]}$ : Tibet Plateau Salt Lake Area, Northwest Salt Lake Area, Northeast Salt Lake Area and East Scattered Salt Lake. Generally, Tibet Plateau Salt Lake Area is famous for being rich in potassium, magnesium, boron and lithium resources. Northwest Salt Lake has formed large-scale nitrate resources in the Gobi area 
due to the drought climate and the extremely high temperature in summer. Northeast salt lake mainly possess mirabilite, trona and halite. East Scattered Salt Lake Area mainly develops some modern small-scale salt lake with different resources ${ }^{[2,3]}$.

Jianghan Basin is a typical Mesozoic-Cenozoic salt lake of East China, in which big area of Salty-tasting series of strata develop, the previous research has testified that in the basin Paleocene Shashi Formation deposited potassium content brine. Eocene Qianjiang Formation all contains potassium salts upside ${ }^{[4]}$. But Xingouzui Formation for this research was found oil and gas resources with industrial utilization value during the process of exploration and development in recent years, and the formation of oil and gas is closely related to the salty-tasting series of strata ${ }^{[4,5]}$. In view of this, This research is aimed at to explore the relationship between Xingouzui Formation salty-tasting series of strata and oil and gas resources, which has a great significance for the better understanding of the character of Jianghan Basin Salt Lake deposition and exploration of the oil and gas resources in future.

\section{Methods and Results}

The study area was located in the south of Qianjiang depression of Jianghan Basin and the target stratum is Xingouzui Formation(Fig1). The foundational materials for this research includes core from 4 coring wells which is totally $570.41 \mathrm{~m}$ and relevant well logging, rock slice, scanning electron microscope and so on.

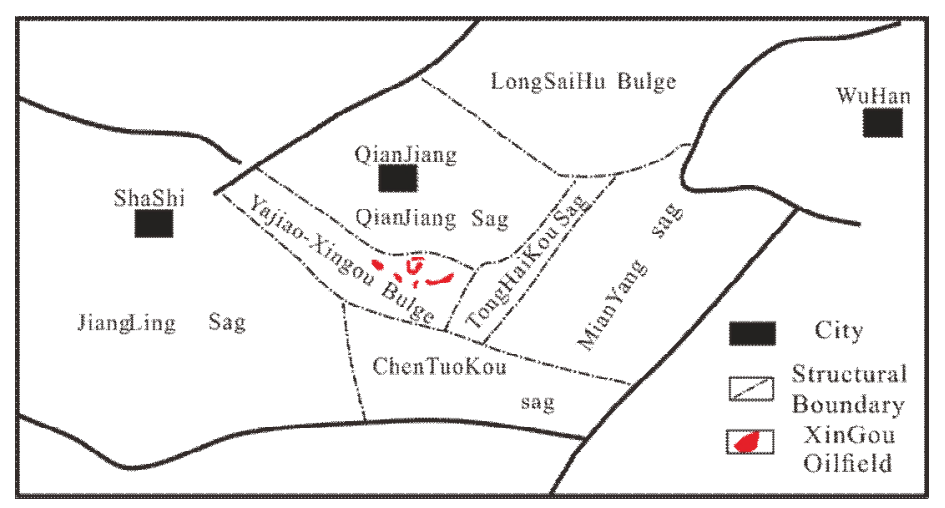

Fig.1 Location of Xingou Oilfield in Jianghan Basin

Firstly core of 4 coring wells was detailedly analyzed in terms of the colours, lithology and sedimentary structures. Three dominated lithology of mud-stone, dolomite and gypsum, in addation, a large number of transitional lithology such as dolomitic mud-stone, argillaceous gypsum and so on induced by different contents of dolomite and gypsum were also identified. Rhythmicity of the different lithology which is characterized as overlaying gypsum-dolomite-mudstone or argillaceous gypsum- dolomitic mudstone - mudstone etc. was recognized by analyzing vertical pattern of different lithology. This rhythmicity was called salt rhythm which was induced by contraction or expansion of salt lake, it is further impacted by tectonic movement, paleoclimate and diagenesis. As far as Xingouzui formation, a complete sedimentary sequence composed of gypsum - argillaceous gypsum-dolomite- dolomitic mudstone-mudstone-dolomitic mudstone- dolomite- argillaceous gypsum- gypsum during the process of contraction to expansion of salt lake. Obviously, the ideal complete salt rhythm was not existed and the ones that can be recognized were always composed of several components of the complete sedimentary sequence. Furthermore, four different orders of the salt rhythm were identified from I-order to IV-order based on their thickness and mineral components. Formation of different orders salt rhythm highlights the complex influence of changes 
of tectonic, paleoclimate, lake level in different time periods, among which the lake level variation might be the most important and direct factor. For an illustration, the IV-order salt rhythm was the direct response to the minimum variation of the lake level and it was only centimeters to several meters, it has been playing an important role in supplying information about paleoclimate variation in minimum time periods which is about 0.5 to $1.0 \mathrm{ka}^{[5]}$.

Then formation mechanism of salt rhythm was discussed and depositional model of the salt lake in Xingouzui Formation period was established in this paper. The lake level variation might be the most important and direct factor for deposition of the salt rhythm. Gypsum was deposited in the center of basin when the lake level was relatively low which is induced by little fresh water poured into(Figure 2-A), while the mudstone would deposit on it when the lake level suddenly increased due to strong rainfall or sudden flood, later then, dolomite would develop with slow decline of lake level(Figure 2-B), again, new gypsum would deposit when the lake level decreased to a very low stage(Figure 2-C). Thus, salt rhythm would develop vertically during the process of lake level varied from increase to decrease.

\section{Discussion}

3.1 Salt lake deposition is significant for indicating paleoclimate

As we all know, salt lake deposition is commonly developed in arid climate which can be further divided into warm-arid and cold-arid climate based on different saline mineral. For instance,
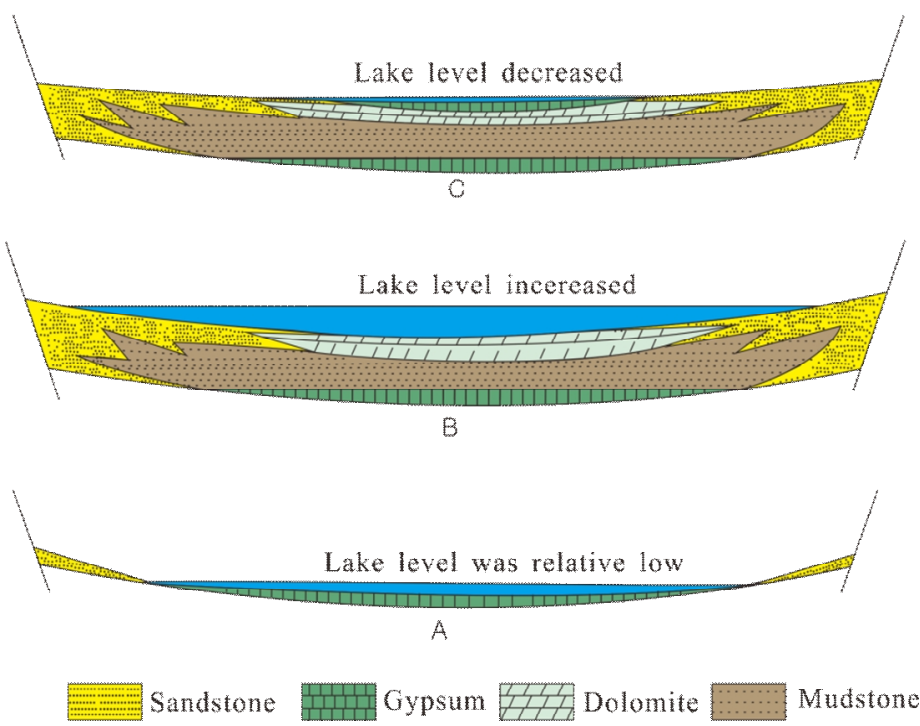

Fig. 2 Mode pattern of salt lake deposition of the Xingouzui Formation in Xingou Oilfield, Jinghan Basin(modified from Ji etc.2003)

mirabilite is the typical represent of cold-arid climate while thermonatrite is represent of warm-arid climate $^{[1]}$. Mineral components analysis of Xingouzui Formation indicate that the dominant mineral is doloimite, calcite and so on that is represent of eury-thermal saline minerals(Table1), then semiarid-arid paleoclimate when the temperature was neither too hot nor too cold was recognized based on the mineral characteristics.

3.2 Salt lake deposition is significant for oil and gas exploration

The process of salt lake deposition provided useful conditions for the development of high quality hydrocarbon source ${ }^{[6]}$. Masses biont would die during the process of salinity increase induced by decline of lake level, however, masses biont would be brought into lake when strong rainfall or sudden flood happened. Then pelphyte would develop in the lakebed during the circulation of biont demise and supply. By this, high quality hydrocarbon source was formed to 
provide material basis for oil and gas generation. Furthermore, sub-oxidation to reduction environ-

Table 1 Mineral distribution in reservoir of the Xingouzui Formation in Xingou Oilfield

\begin{tabular}{ccccccccc}
\hline \multirow{2}{*}{$\begin{array}{c}\text { 样品 } \\
\text { 编号 }\end{array}$} & \multicolumn{7}{c}{ 矿物成分/\% } \\
\cline { 2 - 9 } & 白云石 & 方解石 & 黄铁矿 & 方沸石 & 石英 & 长石 & 岩屑 & 泥质 \\
\hline 1 & 30 & 30 & 3 & 0 & 2 & 8 & 1 & 26 \\
2 & 52 & 12 & 2 & 1 & 2 & 5 & 1 & 25 \\
3 & 47 & 4 & 1 & 2 & 7 & 8 & 8 & 23 \\
4 & 89 & 5 & 1 & 1 & 0 & 0 & 1 & 3 \\
5 & 76 & 5 & 2 & 3 & 3 & 4 & 1 & 6 \\
6 & 77 & 3 & 1 & 0 & 3 & 4 & 2 & 10 \\
\hline
\end{tabular}

ment in lakebed gave advantage to organism preservation ${ }^{[7]}$. Gypsum deposited in salt lake could also catalyze thermal cracking of hydrocarbon source by which the speed for oil and gas generation would accelerate. As mentioned before, salt rhythm sequence was composed of mudstone, dolomite and gypsum, mudstone was rich of organism, while the dolomite would be useful reservoir to oil and gas, and the gypsum would be favourable caprock based on its stable density and high threshold pressure $^{[8]}$. Above all, an relative complete salt rhythm sequence would be a suite of generation-reservoir -caprock assemblage, so the salt rhythm deposition should be given concentration in salt lake study in future.

\section{Acknowledgements}

This work was financially supported by the program supported by national natural science foundation(41302096) and Jianghan Oil Production Plant of SINOPEC.

\section{References}

[1]Zheng M P , Qi W, Jiang X F, Zhao Y Y, Li M H: Trend of Salt Lake Changes in the Background of Global Warming and Tactics for Adaptation to the Changes. Acta Geologica Sinica (English Ed.)Journal of the Geological Society of China. Vol.78(2004), p.795 807 .

[2]Li M H , Kang S C, Zheng M P: Saline Sedmientary Rhythm of Qiuli'nanmu Lake in Tibet. Geological Journal of China Universities. Vol.13 (2007), p.35 42.

[3]Zheng M P: Salt Lake Resources and Eco-environment in China. Acta Geologica Sinica. Vol.84 (2010), p.1613 1622.

[4]Zhang Y S, Wang G L, Yang Y Q: Rhythms of saline lake sediments of the Pale- ogene and their Paleoclimate significance in Qianjiang Sag, Jianghan Basin. Journal of Palageography. Vol.7

(2005), p.461 470 .

[5]Wang C L, Liu C L, Hu H B: Sedimentary characteristics and its environmental significance of salt-bearing strata of the Member 4 of Paleocene Shashi Formation in southern margin of Jiangling Depression ,Jianghan Basin. Journal of Palageography. Vol.14 (2012), p.165 175.

[6] Downey M W: Evaluating seals for hydrocarbon accumulations. AAPG Bulletin. Vol.68(1984),p.1752 1763.

[7] Johannes S, Janos L U ,Peter A K: Limite to the sealing capacity of rock salt: A case study of 
the infra-Cambrian Ara Salt from the Sounth Oman salt basin. AAPG Bulletin. Vol.91(2007),p. $1541 \sim 1557$.

[8] Wang D X, Zeng J H, Gong X M:IMPACT OF GYPSOLITH ON THE FORMATION OF

OIL\& GAS RESERVOIR. NAT URAL GAS GEOSCIEN CE. Vol.16(2005),p. 329 333. 